\title{
Wildlife and Land Use in Highland Scotland
}

\author{
James Lockie
}

Depopulation of the Scottish Highlands in the seventeenth century was followed by intense exploitation and often misuse of the land, with serious overgrazing, burning and wildlife destruction. Today the main land uses are hill sheep farming, crofting, sport, and, more recently, commercial timber growing, nature conservation, hydroelectric schemes and tourism. The author, who is on the staff of the Department of Forestry and Natural Resources in Edinburgh University, examines the effect of these activities on four main wildlife species - golden eagle, red deer, red grouse and red fox and describes some of the mistaken management practices which damage the wildlife, often without producing the desired results.

They say in Scotland that 'guid gear goes into small bulk'. Most Scots would apply this to their country, for Scotland is small but varied. It has the oldest and youngest and richest and poorest rocks; it has a dry east coast and a rain-sodden west with peat bogs; it has cool areas and warm areas where subtropical palms grow well; from rocky or sandy shore to arctic alpine mountain tops may be only a few miles; it has large inland waters like Loch Ness and a west coast with sea arms that cut 20 miles into the mainland. All this is in a country 200 miles by 80 .

Scotland has had human occupation from earliest times and a rich fauna that included wolves, brown bears, lynx and white-tailed eagle, now all extinct there. The landscape we have now and the wildlife that inhabits it can only be understood by reference to the social, political, and economic factors that have interacted and still interact with the physical environment.

About 3000 BC Scotland was heavily forested. From the beginnings of agriculture, areas of forest were cleared first by burning, then by cutting; and the clearance intensified under settled agriculture and pastoralism. In the centuries that followed, AngloSaxons, Romans and Scots from Ireland continued to clear more forest, and further tracts were destroyed in Viking and clan raids.

The seventeenth century saw the start of forest clearance for commercial purposes when the oak and pine forests of Highland Scotland were used for iron smelting and boat building. After the crushing of the 1745 uprising a form of feudalism replaced the clan system in the Highlands and exploitation of the land's resources was greatly accelerated. Sheep graziers from the south moved north to occupy much of the Highlands and continued the forest destruction by felling, burning and barking trees and preventing most tree regeneration. The ending of clan warfare, followed by the introduction of the potato as a staple food, led to a population 
explosion in the Highlands, and this was made one of the excuses for the simultaneous clearance of the human inhabitants from whole districts to make way for flocks of Blackface and Cheviot sheep. The dispossessed people drifted south to the developing industrial areas, emigrated to USA, Canada, Australia, or accepted the tiny inhospitable holdings or crofts offered to them along the Atlantic coast where they eked out a living by fishing and subsistence agriculture.

The nineteenth century also saw the development of grouse moor and deer forest. The first is an area managed to control the heather plant Calluna vulgaris and encourage large numbers of the red grouse Lagopus scoticus, the game bird that depends on it; deer forest is an open area (often without trees) of moor, bog, and mountain on which the Scottish red deer Cervus elaphus live. Grouse shooting and deer stalking became fashionable sports among the new class of wealthy industrialists that was forming in the south and sometimes displaced the earlier sheep runs. Thus while a reduction in human population is often recommended as a prerequisite for an improvement in land use, the savage depopulation of Highland Scotland merely began an era of intensified exploitation and often extensive misuse of the land by overgrazing, burning and wildlife destruction. In this century, two new forms of land use have taken their place beside hill sheep farming, crofting and sport: commercial timber-growing by the state and by private landowners, and nature conservation by the state and other public bodies. Added to these are hydroelectric schemes and a rapidly growing tourist industry.

All this has had and continues to have a profound effect on wildlife, and, since the balance between these uses of the land is not yet resolved, we can expect further changes in the future. We can see more clearly the nature of these changes by considering four important animals in Highland Scotland and the effect of land use upon them: the golden eagle Aquila chrysaëtos, red deer, red grouse and red fox Vulpes vulpes.

\section{Golden Eagles' 'Sins'}

The golden eagle is specially protected, and convicted lawbreakers face heavy fines. Despite this, it is often illegally killed in remote hill country. Since few nature reserves can wholly maintain a pair of eagles with a territory of from 5000-20,000 acres the future of golden eagles lies largely outside nature reserves. The dangers to this species stem from two complaints: that it kills lambs and that it kills red grouse. It is noteworthy that eagles in the eastern Highlands, where wild prey is plentiful, rarely eat lambs, whereas in the west, where wild prey is generally scarce they do so regularly. Indeed, there are few pairs of eagles in Wester Ross that have not at some time brought lambs to the eyrie. The inference that lamb is not preferred prey is supported by the fact that, in the West Highlands, the eagles that do not bring lambs to the nest always have some suitable and locally abundant prey such as rabbit or hare. 
The eating of a lamb does not necessarily mean that the eagle killed it, as can be shown by examining lambs brought to the eyrie. A lamb killed by an eagle shows a large area of bruised blood under the skin of the nape and rump; otherwise it shows only talon marks and no blood. If the eyes are out, a crow has been at the lamb first. If the ears and tail are chopped off, a fox has been there first. With these facts in mind I estimated that one pair of eagles killed only one third of the lambs they brought to the eyrie; the remainder were picked up dead.

The winter food of eagles comprises a great deal of carrion, both sheep and deer. Measurements of the amount of suitable live wild prey on these western mountains, by Leslie Brown and Adam Watson, show that in many years there is insufficient to keep a pair of eagles going. They therefore seem to depend on the carrion.

\section{Carrion Supply}

Why is wild prey scarce and why are there dead lambs and dead sheep and deer in the hills in such plenty? The reasons are various. Until recently red deer were undercropped, the hills were overpopulated and many deer died each winter. Sheep, too, are often overstocked. Increases in shepherd's pay makes it necessary for one shepherd to look after more sheep, which he may do less well, particularly in the more rugged terrain. Prolonged heavy grazing has changed the quality of many hill-grazings for the worse, so that sheep find it increasingly difficult to produce enough to pay their way. Lastly, the use of uncontrolled fire has accelerated erosion and has changed the vegetation to fire resistant but unpalatable species. All these factors have been at work, and the result is a misused landscape where wildlife is, in general, scarcer than it used to be. It is paradoxical that the very industry that complains of eagles as pests is the one that has reduced the eagles' wild prey and then perpetuated high numbers of eagles by deaths in its own flocks. There were a few years in the early 1960 s when the breeding success of eagles and other raptors was reduced due to dieldrin and perhaps DDT eaten with mutton flesh and fat. But dieldrin has been withdrawn from use in sheep dips against ectoparasites and the breeding of eagles is now back to normal.

In the eastern Highlands, in contrast, eagles are more closely linked to grouse moor management. Here they are often shot or trapped because of the grouse they eat or scare from the moor when shooting is in progress. The Nature Conservancy Unit of Grouse and Moorland Ecology has demonstrated for grouse the truth of Paul Errington's contention that superfluous birds are those most vulnerable to predation. Since these grouse are surplus to the carrying capacity of the heather habitat their loss does not affect the crop, for they cannot breed and are doomed to die from starvation, disease, predation or accidents. This research demonstrates that the continuing war against some bird predators is stupid since it serves no purpose in conserving grouse stocks.

Much of what has been said about eagles applies also to foxes. 


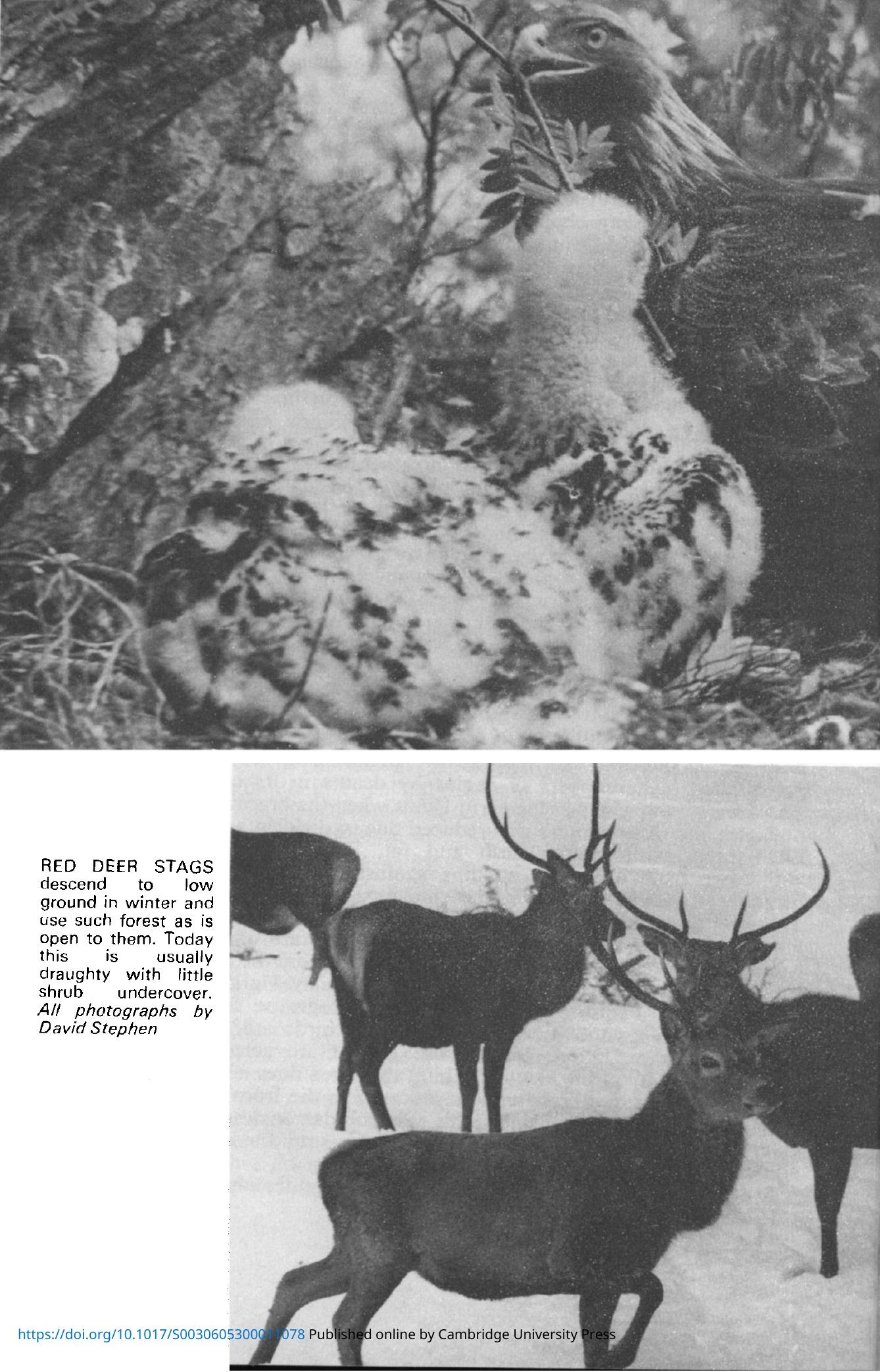


Lamb killing is the main problem. The fox undoubtedly takes lambs at times, and some people may feel that this is reason enough for the almost hysterical annual onslaught on foxes with guns, traps, poison, snares and dogs. But the ecologist would want a little more information before passing judgment.

It is well known that the fox is a scavenger, an eater of lamb and sheep carrion. The question to which there is no answer yet is: what proportion of lambs picked up by foxes are already dead? The ecologist would want to know what foxes normally eat since they cannot live on lambs throughout the year. In the Scottish Highlands the fox's food includes red grouse, hares, rabbits, deer calves, lambs, deer and mutton carrion and large numbers of short-tailed voles Microtus agrestis. Voles are wholly vegetarian and feed on the best grasses. They eat twice their weight, about 60 grams, in green grass each day; in a countryside short of nutritious grass in winter they probably compete with sheep and deer. The voles are also hosts for the early stages of the tick which transmits a virus disease of hill sheep called 'louping ill'. The disease is a major veterinary problem on many hill sheep farms. When their population density is high the voles and other small mammals can be important as amplifiers of infection, for more juvenile ticks can feed and survive. In addition, a proportion of ticks become carriers of the virus; together, these increase the risk of infection of sheep in subsequent years. A similar situation has been described in Czechoslovakia where after 'mouse' or 'vole years' there are outbreaks of tick-borne encephalitis in human beings.

A strong and varied predator force that can flatten out the peaks of vole abundance might help to reduce the prevalence of the disease. Likewise any reduction in vole numbers in winter is a saving of green grass. Weasels, stoats, short-eared owls and foxes provide one such force.

\section{A Time for Fox Control}

These relationships are real enough even if we do not know their relative importance; they are mentioned because the prevalent attitude that 'the only good fox is a dead fox' hides many aspects of fox ecology that may be of economic benefit to the very sheep farmers who complain most about foxes. Until we do know, however, a compromise control scheme may give us the best of both worlds. Lamb-killing usually stops when the parent foxes are no longer under pressure to kill for their cubs. The time to control foxes in the interests of sheep farming is, therefore, when they are feeding cubs, and this is current policy. But the war against adult foxes continues throughout the year, even when they do no harm to sheep. Why not, therefore, leave the adults alone so they may kill voles for ten months of the year? Some measurements that W. N. Charles and I did of predation on voles in winter by weasels, owls and foxes showed that the predator force alone reduced the voles from 90 per acre to 45 per acre.

The red grouse is a famous game bird indigenous to Scotland. 


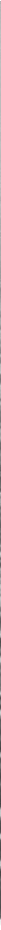

RED GROUSE HEN. Usually the nest is in longish heather which provides cover, shelter and most of the adult birds' food

Grouse shooting is a rich man's sport. The usual method of shooting is to build waist-high walls of turf or peat (called butts) at intervals across a hillside. The shooters stand behind these with a gun bearer who loads the shotguns quickly and passes them to the shooter. Beaters move in line-abreast and drive the grouse downwind over the shooters. A grouse moving downwind at $60 \mathrm{mph}$ is a small target so the shooting has to be fast and accurate. This method requires very high numbers of grouse on the ground. The other method, used where grouse are scarcer, is to walk up individual birds with dogs and shoot them as they fly off. In the original vegetation of the Scottish Highlands red grouse must have been thin on the ground and confined to the dwarf heather between the tree line and the altitudinal limit of heather and also to open areas in the forest. Deforestation presented the red grouse with new and extensive heather-dominated habitats at low levels.

Management for grouse has consisted of a strange combination of good sense and crazy notions. For the last 100 years the main activities have been heather burning, predator control and limited shooting to leave ample stock for breeding in the next year. Only recently has research by the Nature Conservancy Unit of Grouse and Moorland Ecology clarified the relative importance of these activities, showing that grouse shooting over butts never exploited the annual production of the birds to the full. This was evident because, after the shooting season, the grouse adjusted to a still 
lower level of numbers and, by territorial display, ejected a surplus of birds. These were driven out to areas marginal for grouse, such as the grassy edges of streams and areas of poor heather, where their losses were higher than those sustained by the resident territory holders. Many deaths were due to predation, but the surplus birds were also less well nourished and carried a heavy load of parasites. Whatever agency killed them hardly mattered since they were a doomed surplus except for those that replaced the occasional territory holder that died.

Thus two notions in grouse management which had persisted for a century were laid low. The unit showed that predation in winter did not affect the stock of grouse surviving to breed in the next spring, and second, that the practice of saving birds for breeding had nothing to recommend it; the grouse decided for themselves.

The number and size of eggs, the hatching date, chick weights and hatching and rearing success all varied from year to year. All tended to be larger in years with early nesting leading to good breeding success, whereas all were smaller in years when nesting was late. In years of good breeding, the adults survived well through the winter before the breeding season; in years of poor breeding they survived less well. This suggested that the survival of chicks was conditioned by events affecting adults before the eggs were laid, and the Unit confirmed this experimentally by taking eggs from wild grouse in different study areas and hatching and rearing them in captivity.

Food is the factor most likely to affect the condition of adults and the quality of their eggs. The quality of heather, the staple food of grouse, is influenced mainly by its growth in the preceding summer, and the Grouse Unit found a significant correlation between breeding success one year and heather growth in the previous year. They concluded that, in most years, breeding success depended on the bodily condition of resident breeders just before the eggs were laid. Another related problem was why different moors have different average densities of grouse. Generally speaking, those moors that were on good soil-forming rocks always had good breeding success and stable populations, whereas those on poor soilforming rocks had unstable populations. That is, territorial behaviour, acting as a buffer between population size and perhaps the heather food resource, worked more strongly in good habitats.

The key to grouse moor management is clearly habitat management and this means heather management. Grouse hold territories of from 5-10 acres and, within this area, ideally there should be medium-aged heather that is nutritious and provides shelter, old heather which provides cover for moulting and escape from enemies, and areas of young developing heather. The means of achieving this is by fire. The plant has a cycle of from 15-40 years when trees invade and the succession proceeds. By burning heather the succession is put back to the earliest stage; and by rotational burning the succession is halted at heather moorland. From the game manager's and the grouse's point of view the ideal size of fire is about one acre. Therefore on a 10,000 acre grouse moor with a 10- 
12 year burning rotation the ideal would be 1000 fires annually of one acre. However, because the law allows burning only between certain dates, and because of a shortage of labour this ideal is rarely achieved, although the best grouse moors come close to it.

The success of burning heather is most evident in the eastern Highlands of Scotland where the accidents of climate and topography make it fairly easy to maintain the heather cover. As one moves west the climate becomes wetter, the slopes often steeper and the underlying rocks poorer. Burning under these circumstances must be done with ecological good sense; without it heather can easily be replaced by grass and erosion easily accelerated.

In the West Highlands burning as a management tool just for grouse. then for sheep and deer, was taken from the east and applied without much thought; out of this has developed a tradition of burning the heather each spring. No attempt is made to control the fires and great areas go up in smoke each year. Towards the end of April the whole landscape is blue-shadowed with a pall of smoke that may be almost continuous for two hundred miles. The effect of uncontrolled fire in the west is to change the vegetation from heather, sedge and grass to a sedge and grass-dominant community. On steep slopes with a heavy rainfall accelerated erosion is often serious. The combined effect has been to make the country less habitable for grouse in particular and wildlife in general. Despite the cries that hooded crows, or foxes, or eagles, or the Forestry Commission (by harbouring predators) is the cause of the decline in grouse numbers, it seems much more likely that man's own mis-use of fire is the root cause. As with so many wildlife-land use problems, a solution lies in educating people; but we have a long way to go.

\section{Conflicts over the Red Deer}

The red deer in the Highlands are descendants of animals that once lived largely in forest, as they still do on the continent of Europe. In Scotland, some have returned to forest-living now that extensive forests have been planted by the Forestry Commission, although generally fencing keeps them out. Most red deer thus live on the open hill and may hardly come in contact with trees, far less forests, all their lives. Such deer vary in size, but a reasonable average weight for stags would be $200 \mathrm{lbs}$ which makes them midgets beside the elk of North America (which are close relatives) and the red deer of Central Europe. Even so they are fine animals and the largest land animal in Britain. They are, however, different things to different people; they are a famous game animal; they are a favourite with tourists and naturalists; they are potential competitors with farm stock and can raid farm crops; they browse forest trees and sometimes strip bark; they are an important part of Scotland's heritage of wildlife. Red deer are thus viewed very differently by the different users of hill land, and this is where the conflicts lie.

The traditional means of hunting red deer in Scotland which began around 1850 was to stalk up close to the animals in open 
country using gullies and knolls downwind, in order to keep out of sight and smell. Usually a stalker, an employee of the estate who knew the lie of the land, guided the hunter. In the latter half of the 19 th century it became fashionable for rich industrialists to own a deer forest, which they visited for deer stalking and perhaps salmon and trout fishing for a few months in the year. The emphasis was usually on trophy shooting, big much-forked antlers being especially coveted. The shooting of hinds (females), however, was looked upon as a chore and therefore left to the local staff, who usually tended to undershoot, and the tendency became more and more pronounced as staff problems during this century became more acute. Added to this was the intuitive feeling of stalkers that if you leave plenty of hinds you will get plenty of stags. All one really does by adopting this policy is to ensure a very high mortality when a bad winter comes and a generally poor size and antler quality in adult beasts.

The result was similar to that of the 'buck law' in the USA. Deer populations increased greatly and pushed out onto agricultural land where they should not have been. At the same time, afforestation by the state was proceeding, often on a large scale. The Forestry Commission remit meant that it was primarily concerned with growing timber and looked upon deer, often rightly, as forest pests to be excluded by high fencing. However, the siting of fences took no account of the seasonal movements of deer and often aggravated the conflict with agriculture by diverting deer to arable land.

It was in this climate of opinion that gang poaching at night began on a grand scale. Poaching was often brutal, many animals being left wounded. Even so, it was applauded by some people as a means of controlling a pest, and a Government Committee was unable to agree on the question of close seasons. Later, a second Committee did. Eventually in 1958, the Red Deer Commission was set up to advise on management. They have now censused most of the land occupied by red deer, of which there are about 200,000 . They have also advised estates on the correct cropping rate so that the annual production is fully utilised. And they have helped exterminate deer on land where they cannot be permitted. The Forestry Commission has also changed its policy towards deer and tries more and more to accommodate the deer by providing access to low ground.

This is a time of great change in the Scottish Highlands. The old idea of an estate as a sporting plaything is less easy to maintain today because of a revision in tax laws. Thus estates must be made to pay their way. And this need comes at a time when the traditional extensive hill-sheep industry is in difficulties because of rising costs and shortage of labour. Some estate owners, realising how well red deer are adapted to their hill environment, are harvesting deer primarily for venison, a very great break with tradition.

Red deer are remarkably free from diseases and parasites, nasal bot flies and warbles being the most prevalent. They use the hills more efficiently than sheep since they move across the contours rapidly as the fickle Scottish weather changes. All parts of the deer 
are in demand, the skin and antlers for tourist trinkets, the canines for tie pins in Germany, and the venison, which has doubled its price in the last two years, for food. The overheads for cropping deer are smaller than those for herding sheep.

There is therefore an incentive to crop red deer. Alongside cropping schemes there must be research that guides management and already the Nature Conservancy and universities are contributing useful work. It may be that by having a cash as well as a sporting value the red deer population of the Scottish Highlands will be safeguarded more efficiently than by laws alone which rarely take changing land use into account.

Reprinted from Natural History. February 1971. Copyright 1971 by the American Museum of Natural History.

\section{Half-a-Million Pounds for Conservation}

How does the World Wildlife Fund spend its money? In 1970-71 $£ 551,324$ was spent on over 100 projects, and the bulk of the 300page World Wildlife Yearbook, edited by Peter Jackson, the Fund's Information Officer, is devoted to accounts of rather more than half of them. And a wonderful variety it is: fact-finding surveys such as those of Dr Hubert Hendricks on the man-eater tiger problem in the Sunderbans in Bangladesh, Dr Hans Klingel on the status of the Somali wild ass, and the report on the brown bear in Italy's Abruzzo National Park, to which FPS contributed; reports on scientific research, such as those on the wolf in Alaska, the Javan rhino in Indonesia, the walia ibex in Ethiopia; accounts of practical work such as that on the totoaba, a highly endangered endemic fish in the Gulf of California, and captive breeding projects, including the Arabian oryx at Phoenix and giant tortoises in the Galapagos; large gifts of equipment such as the helicopter to Zambia for antipoaching work, thanks to David Shepherd; and, perhaps less exciting but quite essential, the funding given to meetings of experts, such as the Turtle and other IUCN Groups and of organisations, including the International Council for Bird Preservation, the International Youth Federation and IUCN itself.

This was the year of WWF's 10th anniversary-there is an account of the celebrations - and the Director General, Fritz Vollmar, could justifiably claim it was WWF's 'most successful year so far.' The story that is summarised here makes one wonder what would have happened to the world's wildlife if a group of far-sighted people had not got together and launched the Fund whose contribution to and importance for wildlife conservation increase with every year.

\section{Correction}

Ian Strange asks as to correct a wrong figure in his article Wildlife in the Falklands in the January 1972 issue. On page 253, in the first paragraph below the heading 'Penguin Harvest', line 5 should read: 'payment of five shillings per 1000 eggs ...' (not per 100). 